\title{
Seed Yield and Growth of Onion as Influenced by Soil and Foliar Application of Boron
}

\author{
R. N. Katkar ${ }^{1}$, S. S. Hadole ${ }^{1}$, S. R. Lakhe $^{1}$, S. M. Ghawade ${ }^{2}$, P. A. Sarap ${ }^{1 *}$, A. B. Age ${ }^{1}$, \\ D. S. Phad ${ }^{2}$, Abhilasha Kharkar ${ }^{2}$, Mohammad Sajid ${ }^{3}$ and S.D. Nandurkar ${ }^{1}$ \\ ${ }^{1}$ AICRP on Micro and Secondary Nutrients and Pollutant Elements in \\ Soils and Plants, Department of Soil Science and Agricultural Chemistry, \\ Dr. Panjabrao Deshmukh Krishi Vidyapeeth, Akola- 444104 (M.S.), India \\ ${ }^{2}$ Chilli and Vegetables Research Unit, Dr.PDKV., Akola- 444104 (M.S.), India \\ ${ }^{3}$ Agriculture Technical School, Nimbi, Dr.PDKV., Akola- 444104 (M.S.), India \\ *Corresponding author
}

\section{A B S T R A C T}

The experiment was conducted at Dr. Panjabrao Deshmukh Krishi Vidyapeeth, Akola to study the effect of boron application on seed yield and growth of onion on Inceptisol in randomized block design with seven treatments and three replications fertilized with different levels of boron during Rabi season of 2014-15 to 2016-17. The treatments

\section{Keywords}

Onion, Boron, Foliar application, Soil

Article Info

Accepted:

14 June 2020 Available Online: 10 July 2020 consisted of different levels of boron in onion through soil and foliar applications viz., $\mathrm{T}_{1}-$ Control, $\mathrm{T}_{2}$ - soil application of borax @1.5 $\mathrm{kg} \mathrm{ha}^{-1}, \mathrm{~T}_{3}$ - soil application of borax @ 3.0 $\mathrm{kg} \mathrm{ha}{ }^{-1}, \mathrm{~T}_{4}$ - soil application of borax @ $5.0 \mathrm{~kg} \mathrm{ha}^{-1}, \mathrm{~T}_{5}$ - foliar application of borax @ $0.1 \%$ at buttoning stage, $\mathrm{T}_{6}$ - foliar application of borax @ $0.2 \%$ at buttoning stage, $\mathrm{T}_{7}$ foliar application of borax @ $0.3 \%$ at buttoning stage. Significantly the highest seed yield (12.32 $\mathrm{q} \mathrm{ha}^{-1}$ ) was recorded with foliar application of borax @ 0.2\% at buttoning stage (60 DAP) $\left(\mathrm{T}_{6}\right)$ followed by foliar application of borax @ $0.3 \%$ at buttoning stage $\left(12.00 \mathrm{q} \mathrm{ha}^{-1}\right)$ $\left(\mathrm{T}_{7}\right)$ which was statistically at par with soil application of borax @ $3.0 \mathrm{~kg} \mathrm{ha}^{-1}$ (11.19 q $\left.\mathrm{ha}^{-1}\right)\left(\mathrm{T}_{3}\right)$. In the present investigation, significantly the maximum total number of umbels (12.49) and test weight (5.09 gm) of seed were found with the foliar application of borax @ $0.2 \%$ at buttoning stage (60 DAP) which was at par with foliar application of borax @ $0.3 \%$ followed by soil application of borax @ $3.0 \mathrm{~kg} \mathrm{ha}^{-1}$ as yield contributing characters. The highest B:C ratio was recorded with foliar application of borax @ $0.2 \%$ (3.54) followed by foliar application of borax @ 0.3\% (3.42) and soil application of borax @ 5.0 $\mathrm{kg} \mathrm{ha}^{-1}$ (3.18). Thus, it could be inferred that, the foliar application of borax @ $0.2 \%$ at buttoning stage recorded highest seed yield, number of umbels and umbellate with higher $\mathrm{B}: \mathrm{C}$ ratio.

\section{Introduction}

There is need to identify new seed production pockets, which are having higher production potential e.g. onion seed is traditionally produced in Maharashtra in general and Vidarbha region in particular. The productivity of onion seed is around 700-800 
$\mathrm{kg} \mathrm{ha} \mathrm{h}^{-1}$ (Gupta and Sharma, 2014). Identification of new areas of seed production is also essential to bridge the gap of seed production suddenly due to certain natural calamities, catch the available suitable agro climatic conditions of particular area to boost economic return to the farmers too (Tomar and Yalamalle, 2017). The seed production of onion gives a good benefit to the farmers. Because of the prices of onion seeds are much higher as compared to onion bulb price, which makes benefits to the farmers. So that, farmers tends to increase the area of seed production of onion.

Considering above facts, this region has definite potential to become seed hub of onion in India. The plant requires all the nutrients like macro and micronutrients among that, boron is one of the most important micronutrient for seed production of onion. Because of its role in increasing the pollen tube growth and pollen tube formation during fertilization process which helps in increasing the seed yield of onion and also improving the seed quality. So, for increasing seed yield of onion, there is need to aware the farmers about the role of boron.

In Maharashtra, onion bulb is produced in three season's viz., kharif or rainy, late kharif and rabi or winter. The total annual organised seed production of onion is about 750-800 tonnes against the demand of 4000 tonnes (Singh, 2000). In Maharashtra, there is a demand of 600 tonnes seed per year. While only 300 tonnes of seed is produced. So there is necessary to increase area under seed production programme to produce good quality seeds in large quantity every year, which will acts as a source to increase per hectare seed yield of onion.

The nutritional deficiency of micronutrients like boron is one of the major constrain, which become a serious problem. For seed production of onion, there is necessity of sufficient amount of boron in soils, which is deficient in this region. The farmers are not aware about boron deficiency in their region, which is important for seed production of onion. Presently, the price of onion seeds being higher and cannot be afforded easily by poor farmers for their cultivation. Being seed production is new for the region, there is lack of technological aspects like proper method of seed production, their cultivation practices and proper method of application of boron fertilizers with their proper dose in onion.

The boron enhances growth and contributes for increasing seed yield of onion. Hence, present investigation was carried out at Research Farm, Chilli and Vegetable Research Unit, Dr. PDKV, Akola during three consecutive seasons of rabi, 2015-16 to 201718 to assess the effect of soil and foliar application of boron on growth and yield of onion.

\section{Materials and Methods}

The experiment was carried out at Chilli and Vegetable Research Unit, Dr. PDKV, Akola during rabi season of 2014-15 to 2016-17, in randomized block design with three replications and seven treatments. The bulbs of onion $c v$. Akola Safed were planted in the experimental plot at the spacing $60 \times 30 \mathrm{~cm}$. The basal fertilizer dose of 50: $50: 50 \mathrm{~N}, \mathrm{P}_{2} \mathrm{O}_{5}$ and $\mathrm{K}_{2} \mathrm{O} \mathrm{kg} \mathrm{ha}{ }^{-1}$ was applied and remaining half dose of nitrogen $(50 \mathrm{~kg} \mathrm{~N})$ as top dressed. The treatment wise borax was also applied as basal by mixing with FYM. The foliar sprays of borax were carried out at buttoning stage.

The soil of experimental site was Inceptisol, slightly alkaline, montmorillonitic type, hyperthermic family of Typic Haplusteps. The initial soil analysis indicated that the soil is slightly alkaline in reaction (8.0), moderately calcareous $(4.87 \%)$, medium in 
organic carbon $\left(5.13 \mathrm{~g} \mathrm{~kg}^{-1}\right)$, low in available nitrogen $\left(250.88 \mathrm{~kg} \mathrm{ha}^{-1}\right)$, medium in phosphorus $\left(15.86 \mathrm{~kg} \mathrm{ha}^{-1}\right)$ and very high in potassium $\left(376.32 \mathrm{~kg} \mathrm{ha}^{-1}\right)$, sulphur content was just above the critical level $(10.13 \mathrm{mg} \mathrm{kg}$ $\left.{ }^{1}\right)$, marginal in zinc $\left(0.61 \mathrm{mg} \mathrm{kg}^{-1}\right)$ and iron (4.74 $\left.\mathrm{mg} \mathrm{kg}^{-1}\right)$, moderately high in copper $\left(0.43 \mathrm{mg} \mathrm{kg}^{-1}\right)$ and manganese $\left(4.09 \mathrm{mg} \mathrm{kg}^{-1}\right)$ and deficient in boron content $\left(0.49 \mathrm{mg} \mathrm{kg}^{-1}\right)$.

\section{Results and Discussion}

\section{Effect of boron application on yield and yield attributes}

Seed yield is a complex trait as it is the product of a number of individual yield components. There are many factors that can influence seed yield and seed quality, such as genotype, agronomic techniques and the environment (Bornscheuer et al., 1993; Apostolides and Goulas, 1998). Nutrient fertilization is one of the factors that can have a direct impact on seed yield and seed quality. Boron is one of the essential nutrients for plants and has a direct influence on the flower development, pollen germination, fertilization and seed development (Marschner, 1995; Dell et al., 2002). Boron also plays a significant role in augmenting the yield and yield components of onion seeds. The yield of onion seed increased significantly due to added boron (Noor et al., 2011).

The results revealed that the effect of boron application was found to be significant in respect of seed yield. Among various treatments, significantly highest seed yield (12.32 q ha ${ }^{-1}$ ) was recorded with foliar application of borax @ $0.2 \%$ at buttoning stage (60 DAP) $\left(\mathrm{T}_{6}\right)$ followed by foliar application of borax @0.3\% at buttoning stage $\left(\begin{array}{llllll}12.00 & \mathrm{q} & \mathrm{ha}^{-1} & \left(\mathrm{~T}_{7}\right) & \text { which was }\end{array}\right.$ statistically at par with soil application of borax@3.0 kg ha ${ }^{-1}\left(11.19 \mathrm{q} \mathrm{ha}^{-1}\right)\left(\mathrm{T}_{3}\right)$. Seed yield recorded highest in foliar application of borax@ $0.2 \%$ followed by foliar application
@ 0.3\% and soil application of borax @ 3.0 $\mathrm{kg} \mathrm{ha}^{-1}$ as compared to control.

Among the various methods of borax application, the foliar spray of borax @ 0.2\% or $0.3 \%$ at buttoning stage (60 DAP) and soil application of borax @ $3.0 \mathrm{~kg} \mathrm{ha}^{-1}$ were found better in enhancing seed yield of onion. Gogoi et al., (2012) reported highest seed yield of brinjal $\left(650.23 \mathrm{~kg} \mathrm{ha}^{-1}\right)$ with the foliar application of boron @ $0.25 \%$. Kumar et al., (2014) concluded that foliar spray of borax @ $0.50 \%$ was the best treatment for seed yield in cauliflower (6.44 q ha $\left.{ }^{-1}\right)$. Sharma et al., (1999) registered highest seed yield of radish $\left(10.70 \mathrm{q} \mathrm{ha}^{-1}\right)$ with foliar application of $0.1 \%$ boric acid. The soil application of borax @ $3.0 \mathrm{~kg} \mathrm{ha}^{-1}$ recorded 21.44 per cent lower yield as compared to foliar spray of borax @ $0.2 \%$. Foliar applied boron causes increase in seed yield than soil applied boron. Boron is required more at reproductive stage and foliar applied boron is instantly become available to plant as compared to soil applied boron (Padbhushan and Kumar, 2014). The improvement in yield can be ascribed to boron as it is directly linked with process of fertilization, pollen producing capacity of anther, viability of pollen grains, pollen germination and pollen tube growth (Agarwal et al., 1981, Dickson, 1978, Vaughan, 1997). The basal dose of boron was inductive to vegetative growth characters to a great extent because boron helps in photosynthesis and growth of meristimatic tissues, carbohydrate and auxin metabolism, cell development and differentiation which ultimately increase vegetative growth (Kumar et al., 2014). Hence, foliar as well as soil applied boron increased seed yield of onion.

The seed yield per plant (32.17) was highest in treatment of foliar application of borax @ $0.3 \%$ at buttoning (60 DAP) followed by foliar application of borax @ $0.2 \%$ at buttoning stage (60 DAP) and at par with soil application of borax@3.0 kg ha-1. 


\section{Umbels per plant}

The total umbels consist of number of primary and secondary umbels per plant. The primary umbels were almost higher than the secondary umbels. The results showed total number of umbels per plant varied from 9.79 to 13.86. The significantly highest total number of umbels per plant (13.86) was recorded in the treatment of soil application of borax@5.0 kg ha ${ }^{-1}\left(\mathrm{~T}_{4}\right)$ followed by soil application of borax @ $3.0 \mathrm{~kg} \mathrm{ha}^{-1}$. Malek and Rahim (2011) recorded the highest number of umbels per plant with the soil application of boron@3.0 kg ha-1. Kumar et al., (2014) registered that application of basal dose of borax@ $7.5 \mathrm{~kg} \mathrm{ha}^{-1}$ and foliar spray of borax @ $0.25 \%$ recorded maximum number of snowball cauliflower per plant.

\section{Effect of boron application on quality parameter}

A good quality seed is also one of the important means to increase productivity in any seed crop. Boron played a significant role in augmenting the highest yield and yield components of onion seeds. But a good quality of onion seeds is mainly influenced by test weight and seed germination percentage.

Table.1 Seed yield of onion as influenced by various treatments of boron application (3 years pooled data)

\begin{tabular}{|c|c|c|}
\hline Treatments & $\begin{array}{l}\text { Seed yield per plant } \\
\text { (g) }\end{array}$ & $\begin{array}{l}\text { Seed yield } \\
\left(\mathbf{q} \mathbf{~ h a}^{-1}\right)\end{array}$ \\
\hline $\mathbf{T}_{1}-$ Control & 17.99 & 8.59 \\
\hline$T_{2}-S$. A. of borax @ $1.5 \mathrm{~kg} \mathrm{ha}^{-1}$ & 21.95 & 9.20 \\
\hline$T_{3}$ - S.A. of borax @ $3.0 \mathrm{~kg} \mathrm{ha}^{-1}$ & 24.47 & 11.19 \\
\hline $\mathrm{T}_{4}$ - S. A. of borax @ $5.0 \mathrm{~kg} \mathrm{ha}^{-1}$ & 24.50 & 11.37 \\
\hline $\mathrm{T}_{5}-\mathrm{F}$. A. of borax @ $0.1 \%$ at buttoning stage (60 DAP) & 23.32 & 10.52 \\
\hline $\mathrm{T}_{6}-\mathrm{F}$. A. of borax @ $0.2 \%$ at buttoning stage (60 DAP) & 30.87 & 12.32 \\
\hline $\mathrm{T}_{7}-\mathrm{F}$. A. of borax @ $0.3 \%$ at buttoning stage (60 DAP) & 32.17 & 12.00 \\
\hline SE $(\mathbf{m}) \pm$ & 2.08 & 0.50 \\
\hline CD at $5 \%$ & 6.42 & 1.55 \\
\hline
\end{tabular}

Table.2 Total number of umbels per plant as influenced by various treatments of boron application (3 years pooled data)

\begin{tabular}{|c|c|}
\hline Treatments & Total umbels \\
\hline $\mathbf{T}_{1}$ - Control & 9.79 \\
\hline$T_{2}-$ S. A. of borax @ $1.5 \mathrm{~kg} \mathrm{ha}^{-1}$ & 11.16 \\
\hline$T_{3}-S$. A. of borax @ $3.0 \mathrm{~kg} \mathrm{ha}^{-1}$ & 13.42 \\
\hline$T_{4}-$ S. A. of borax @ $5.0 \mathrm{~kg} \mathrm{ha}^{-1}$ & 13.86 \\
\hline $\mathrm{T}_{5}-\mathrm{F}$. A. of borax @ $0.1 \%$ at buttoning stage (60 DAP) & 11.44 \\
\hline $\mathrm{T}_{6}$ - F. A. of borax @ $0.2 \%$ at buttoning stage (60 DAP) & 12.49 \\
\hline $\mathrm{T}_{7}-\mathrm{F}$. A. of borax @ $0.3 \%$ at buttoning stage (60 DAP) & 12.74 \\
\hline SE (m) \pm & 0.41 \\
\hline CD at $5 \%$ & 1.28 \\
\hline
\end{tabular}


Table.3 Test weight of seed as influenced by various treatments of boron application (3 years pooled data)

\begin{tabular}{|c|c|}
\hline Treatments & $\begin{array}{l}\text { Test weight of seeds } \\
\quad \text { (g/ } 1000 \text { seeds) }\end{array}$ \\
\hline $\mathbf{T}_{1}$ - Control & 3.69 \\
\hline$T_{2}-$ S. A. of borax @ $1.5 \mathrm{~kg} \mathrm{ha}^{-1}$ & 4.22 \\
\hline$T_{3}-$ S. A. of borax @ $3.0 \mathrm{~kg} \mathrm{ha}^{-1}$ & 4.75 \\
\hline$T_{4}-$ S. A. of borax @ $5.0 \mathrm{~kg} \mathrm{ha}^{-1}$ & 4.42 \\
\hline $\mathrm{T}_{5}$ - F. A. of borax @ $0.1 \%$ at buttoning stage (60 DAP) & 4.52 \\
\hline $\mathrm{T}_{6}-\mathrm{F}$. A. of borax @ $0.2 \%$ at buttoning stage (60 DAP) & 5.09 \\
\hline $\mathrm{T}_{7}$ - F. A. of borax @ $0.3 \%$ at buttoning stage (60 DAP) & 4.92 \\
\hline SE (m)士 & 0.12 \\
\hline CD at $5 \%$ & 0.36 \\
\hline
\end{tabular}

Table.5 Gross monetary returns (Rs. $\mathrm{ha}^{-1}$ ) and B:C ratio as influenced by various treatments

\begin{tabular}{|l|c|c|c|c|}
\hline \multicolumn{1}{|c|}{ Treatments } & $\begin{array}{c}\text { Yield } \\
\left(\mathbf{q} \mathbf{~ h a}^{-1}\right)\end{array}$ & GMR & $\begin{array}{c}\text { Cost of } \\
\text { cultivation }\end{array}$ & $\begin{array}{c}\text { B:C } \\
\text { ratio }\end{array}$ \\
\hline $\mathrm{T}_{1}$ - Control & 8.59 & 687111 & 217020 & $\mathbf{2 . 1 7}$ \\
\hline $\mathrm{T}_{2}$ - Soil application of borax @ $1.5 \mathrm{~kg} \mathrm{ha}^{-1}$ & 9.20 & 736267 & 217185 & $\mathbf{2 . 3 9}$ \\
\hline $\mathrm{T}_{3}$ - Soil application of borax @ 3.0 kg ha-1 & 11.19 & 895467 & 217350 & $\mathbf{3 . 1 2}$ \\
\hline $\mathrm{T}_{4}$ - Soil application of borax @ 5.0 kg ha-1 & 11.37 & 909867 & 217570 & $\mathbf{3 . 1 8}$ \\
\hline $\mathrm{T}_{5}$ - Foliar application of borax @ $0.1 \%$ & 10.52 & 841422 & 217053 & $\mathbf{2 . 8 8}$ \\
\hline $\mathrm{T}_{6}$ - Foliar application of borax @ $0.2 \%$ & 12.32 & 985689 & 217086 & $\mathbf{3 . 5 4}$ \\
\hline $\mathrm{T}_{7}$ - Foliar application of borax @ 0.3\% & 12.00 & 959733 & 217119 & $\mathbf{3 . 4 2}$ \\
\hline SE $(\mathrm{m}) \pm$ & $\mathbf{0 . 5 0}$ & $\mathbf{4 0 1 9 6}$ & & \\
\hline CD at 5\% & $\mathbf{1 . 5 5}$ & $\mathbf{1 2 3 8 3 7}$ & & \\
\hline
\end{tabular}

*Cost of planting bulb Rs.100000/ha, Rate of onion seed Rs. 80000/qtl.

\section{Test weight of seeds}

The test weight of seed consists of weight of 1000 seeds (g). The test weight of seed indicates good quality parameter of onion seeds which depends on the boldness of seeds as influenced by various treatments of boron application. The test weight of seeds varied from $3.69 \mathrm{~g}$ to $5.09 \mathrm{~g}$ (Table 3). It increased due to soil and foliar application of borax. The results were significantly influenced in various treatments. Significantly highest test weight of seeds $(5.09 \mathrm{~g})$ was recorded in the treatment of foliar application of borax @ $0.2 \%\left(\mathrm{~T}_{6}\right)$ which was significantly superior with foliar application of borax @ 0.3\% ( $\left.\mathrm{T}_{7}\right)$ $(4.92 \mathrm{~g})$ and the soil application of borax @ $3.0 \mathrm{~kg} \mathrm{ha}^{-1}\left(\mathrm{~T}_{3}\right)$ (4.75 g). It was noticed that, test weight decreased with higher doses of boron by both foliar and soil application. Lowest test weight of seeds (3.69 g) was recorded in treatment control $\left(\mathrm{T}_{1}\right)$. The findings are in line with the results reported by Singh et al., (2014) and they reported that the highest 1000 seed weight was recorded with the foliar spray of boron @ $0.2 \%$. Padbhushan and Kumar (2014) resulted that the maximum mean 1000 seed weight with spraying of $0.1 \%$ borax solution. Davis et al., (2003) also reported similar effect of boron 
application (both foliar and soil) on improved seed weight. Increase in test weight of seeds might be due to boron application influence cell division, carbohydrate metabolism, sugar and starch formation, which increases size and weight of grain (Kalyani et al., 1993).

\section{B:C Ratio}

The highest $\mathrm{B}: \mathrm{C}$ ratio was recorded with foliar application of borax @ $0.2 \%$ (3.54) followed by foliar application of borax @ $0.3 \%$ (3.42) and soil application of borax @ $5.0 \mathrm{~kg} \mathrm{ha}^{-1}(3.18)$.

Conclusion of the study is as follows:

Thus it is inferred that, the foliar application of borax @ 0.2\% at buttoning stage recorded highest seed yield, total number of umbels, test weight of seeds with higher $\mathrm{B}: \mathrm{C}$ ratio.

\section{Acknowledgements}

The author's are highly grateful to the Project Coordinator, AICRP on Micro and Secondary Nutrients and Pollutant Elements in Soils and Plants, IISS, Bhopal, Officer Incharge, Chili and Vegetables Research Unit and Head, Department of Soil Science and Agricultural Chemistry, Dr. PDKV., Akola for providing necessary facilities and funds to carry out this work.

\section{References}

Agarwal, S.C., P.N. Sharma, C. Chaterjee and C.P. Sharma, 1981. Development and enzymatic changes during pollen development in boron deficient maize plant. J. of Plant Nutrition.3: 229-336.

Apostolides, G. and C. Goulas, 1998. Seed crop environment and processing effects on sugar beet (Beta vulgaris) certified hybrid variety seed quality. Seed Science and Tech. 26: 223-235.
Bornscheuer, E., K. Meyerholz and K.H Wunderlich, 1993. Seed production and quality. In the Sugar beer (Eds D.A. Cooke and R.K. Scott). pp. 121-155. London: Chapman and Hall.

Davis, J.M., D.C. Sanders, P.V. Nelson, L. Lengnick and W.J. Sperry, 2003. Boron improves growth, yield, quality and nutrient content in tomato. J. Amer. Soc. Hort. Sci. 128(3): 441-446.

Dell, B., L. Huang and R.W. Bell, 2002. Boron in plant reproduction. In Boron in Plant and Animal Nutrition (EdsGoldbach, H.E., B. Rerkasem, M.A. Wimmer, P.H. Brown, M. Thellier and R.W. Bell) pp: 103-117. Dordrecht, The Netherlands: Kluwer Academic Publishers

Dickson, D.B., 1978. Influence of borate and pentacrythiol concentrations of germination and tube growth of Illium longiflorum pollen. J. of American Soc. for Horticultural Sci. 103: 413-446.

Gogoi, S., M.R. Das, P. Bora and N. Mazumder, 2012. Effect of foliar application of nutrients on fruit and seed production of brinjal (Solanum melongena). Crop Res. 44(3): 366-369.

Gupta, R. P. and Sharma, H. P., 2014. Onion seed production scope, challenges and future strategy to meet the demand of quality seed. In: Brain Stirming Session on crop improvement and seed production of onion, organized at NHRDF, Nashik, 15 March, 2015, pp. $1-12$.

Kalyani, R.R., V.S. Devi, N.V. Satyanarayana and K.V.M. Rao, 1993.Effect of foliar application of boron on crop growth and yield and Pigeonpea. Indian J. of Plant Physio.36: 223-226.

Kumar, C., A.K. Gupta and S.P. Uniyal, 2014. Influence of boron and lime on growth and seed yield of snowball cauliflower (Brassica oleraceavar. botrytis L.) cv. Pusa Snowball K- 
1.Prog.Horti. 46(1): 107-110.

Malek, M.A. and M.A. Rahim, 2011. Effect of boron fertilizer on yield and quality seed production of two varieties of carrot. J. Agrofor. Environ. 5(1): 91-94.

Marschner, H., 1995. Mineral Nutrition of Higher Plants. London: Academic Press, London.

Noor, S., M.H. Ullah and M.A. Kawocher, 2011.Effect of boron and lime on the yield of onion seed in acidic soil. Bangladesh J. Agric. and Environ. 7(2): 24-30.

Padbhushan, R. and D. Kumar, 2014. Influence of soil and foliar applied boron on green gram in calcareous soils. Inter. J. Agri. Env. and Biotech. 7(1): 129-136.

Sharma, S.K., H. Singh and U.K. Kohli, 1999. Influence of boron and zinc on seed yield and quality in radish. Seed Res. 27(2): 154-158.

Singh, K., 2000. Current status of onion and garlic research in India and future prospects. Key note address National Symposium on Onion-Garlic Production and Post- Harvest Management- Challenges and Strategies at Nasik, 19-21 Nov. 2000.

Singh, A.K., Shashank and A. Srivastava, 2014. Effect of boron application on seed yield and protein content of mungbean (Vigna radiata L.).Current Advances in Agril. Sci. 6(1): 67-68.

Tomar B. S. and V. R. Yalamalle, 2017. Improving availability and quality of vegetable seeds for higher profitability. Doubling farmers income through Horticulture, Daya Publishing House, New Delhi.

Vaughan, A.K.F., 1997. The relation between concentration of boron in the reproductive and vegetative organs of maize plants and their development. Rhodesian J. of Agril. Res. 15: 163-170.

\section{How to cite this article:}

Katkar, R. N., S. S. Hadole, S. R. Lakhe, S. M. Ghawade, P. A. Sarap, A. B. Age, D. S. Phad, Abhilasha Kharkar, Mohammad Sajid and Nandurkar, S.D. 2020. Seed Yield and Growth of Onion as Influenced by Soil and Foliar Application of Boron. Int.J.Curr.Microbiol.App.Sci. 9(07): 1459-1465. doi: https://doi.org/10.20546/ijcmas.2020.907.167 